\title{
Csípőarthroscopia: rövid távú eredményeink
}

\author{
Zsákai Zsolt dr. ${ }^{1}$ - Gömöri András dr. ${ }^{2}$ - Papp Miklós dr. ${ }^{1}$
}

${ }^{1}$ Borsod-Abaúj-Zemplén Megyei Kórház és Egyetemi Oktató Kórház, Ortopéd Sebészeti Osztály, Miskolc
${ }^{2}$ Borsod-Abaúj-Zemplén Megyei Kórház és Egyetemi Oktató Kórház, Baleseti Sebészeti Osztály, Miskolc

Bevezetés: A csípőarthroscopia mint minimálinvazív eljárás egyre nagyobb szerepet tölt be a csípőízületi megbetegedések diagnosztikájában és kezelésében. Vizsgálatunkban a csípőarthroscopiának az osztályunkon kialakult gyakorlatát és az ezzel kapcsolatos kezdeti tapasztalatainkat mutatjuk be.

Célkitüzés: Célunk az volt, hogy osztályunk mütéti protokolljába illesszük a csípőarthroscopia eljárását, mert az irodalom áttekintése után, valamint külföldi tanulmányutak tapasztalatát átgondolva reális és sikeres technikának tartjuk ezt a beavatkozást.

Módszer: Az osztályunkon 2017. 01. 01. és 2019. 04. 15. között történt 29 csípőarthroscopia eredményeit vizsgáltuk a pre- és posztoperatív, módosított Harris-csípőpontérték (modified Harris hip score - mHHS) összehasonlításával. A mútéteket 30 fokos optikával, jellemzően standard behatolási kapukból végeztük. A mútéti indikáció jellemzően a csípőütközési (hip impingement) szindróma volt.

Eredmények: Izolált 'cam' (bütyköstengely) típusú deformitást 3, izolált 'pincer' (csipesz) típusú deformitást 9, kevert deformitást 13 esetben észleltünk. A 13 férfi és 16 nő átlagéletkora 44,1 év volt. Legfiatalabb betegünk 22, a legidősebb pedig 60 éves volt. A mútét után az mHHS szignifikáns javulását észleltük mind az F-, mind a Student-féle tpróba szerint

Következtetés: A csípőarthroscopia megfelelő alternatíva a csípő számos betegségének mütéti kezelésében. A 'learning curve' (tanulási görbe) hosszabb ugyan, mint más ízületek tükrözése esetén, a beavatkozás megfelelő szakmai felépítésével azonban a szövődmények kockázata csökkenthető, ezáltal a csípőarthroscopia megoldás lehet a csípő számos megbetegedésének ellátásában.

Orv Hetil. 2020; 161(9): 340-346.

Kulcsszavak: csípőtükrözés, csípőfájdalom, csípőütközési szindróma, arthroscopia

\section{Hip arthroscopy: short-term outcomes}

Introduction: As a minimally invasive procedure, hip arthroscopy plays an increasingly significant role in the diagnostics and management of hip joint diseases. In this study, we present our initial experience with hip arthroscopy established at our department.

Aim: Our aim was to integrate the hip arthroscopy procedure into the surgical protocol of our department, since after reviewing the relevant literature and evaluating our experience gained during study visits abroad, we consider this intervention to be a reasonable and successful technique.

Method: Results of 29 hip arthroscopy interventions performed between 01 January 2017 and 15 April 2019 at our department were evaluated by comparing pre- and postoperative modified Harris hip scores (mHHS). Surgeries were performed with 30-degree scopes, typically via standard access sites. The typical indication for surgery was hip impingement syndrome.

Results: Isolated cam deformity, isolated pincer deformity and mixed deformity were detected in 3, 9 and 13 cases, respectively. The mean age of the 13 male and 16 female subjects was 44.1 years. The age of our patients ranged between 22 years and 60 years. After surgery, significant improvement of mHHS was detected both according to the F-test and the Student's t-test.

Conclusions: Hip arthroscopy is an appropriate treatment alternative for the surgical management of many hip conditions. Even though the learning curve is longer than that of the endoscopic examinations of other joints, adequate surgical design can minimise the risk of complications, making this intervention a potential solution for the management of multiple hip conditions.

Keywords: hip endoscopy, hip pain, hip impingement syndrome, arthroscopy

Zsákai Zs, Gömöri A, Papp M. [Hip arthroscopy: short-term outcomes]. Orv Hetil. 2020; 161(9): 340-346.

(Beérkezett: 2019. október 20,; elfogadva: 2019. november 4.) 


\section{Rövidítések}

a. $=$ arteria $; \mathrm{ALP}=$ anterolateralis portál $; \mathrm{AP}=$ anterior portál; $\mathrm{CT}=$ (computed tomography) számítógépes tomográfia; $\mathrm{LMWH}=($ low-molecular-weight heparin $)$ kis molekulatömegü heparin; MAP $=$ mid-anterior portál; $\mathrm{mHHS}=($ modified Harris hip score) módosított Harris-csípőpontérték; MR = (magnetic resonance) mágneses rezonancia; $\mathrm{n} .=$ nervus; $\mathrm{NT}=$ nagytompor; PLP = posterolateralis portál; $\mathrm{ROM}=$ (range of motion) mozgástartomány; SIAS = spina iliaca anterior superior

Osztályunkon 2017-ben kezdtük el alkalmazni a csípőarthroscopiát mint mütéti eljárást, főként a csípőütközési (hip impingement) szindróma kezelésében a nyílt mütéti eljárás alternatívájaként. A csípőarthroscopia az egyik legnehezebb arthroscopos beavatkozás, ennek megfelelően a 'learning curve' (tanulási görbe) is hosszabb, mint más ízületek tükrözése esetén. Több tanulmány vizsgálja a tapasztalat és a komplikációk kialakulása közti összefüggést. Egy tanulmány szerint 100, önállóan elvégzett csípőarthroscopia után lehet elérni az alap gyakorlati szintet ezen mútéttípusban [1]. Más szerzők szerint évi 60 mütét elvégzése szükséges ahhoz, hogy jelentősen csökkenjen a nagyobb szövődmények kialakulásának veszélye [2].

Tapasztalataink szerint is érdemes - az egyéb mütétekhez hasonlóan, sőt azt meghaladó módon is - hangsúlyt fektetni a preoperatív indikációk felállítására és időt szánni a mútéti technika megfelelő elsajátítására. A hazai viszonyok pedig azt is megkívánják, hogy a mütéti időt, annak tervezhetőségét is érdemes számításba venni, amikor egy osztály a mütéti protokoll listájára szeretné venni ezt az eljárást. Osztályunkon az átlagos mütéti idő 47 perc volt; az első mütétek során természetesen hosszabb időt (90 perc) vett igénybe a megfelelő beavatkozás elvégzése. Az esetszám növekedésével ezt az időt 40 percre sikerült csökkenteni. A nemzetközi irodalmat áttekintve, külföldi tanulmányutakon szerzett tapasztalatokat beépítve, a csípőarthroscopia fokozatosan került be az osztályon végzett mútétek sorába.

\section{A csípőarthroscopia indikációi}

Napjainkban a minimálinvazív eljárásoknak, köztük a csípőarthroscopiának az előnye elvitathatatlan a csípő nyílt mútéti megoldásaihoz képest. Arthroscopia során a szöveti megterhelés kisebb, a neurovascularis sérülések veszélye alacsonyabb, a rehabilitáció pedig gyorsabb [3]. A csípőarthroscopia indikációit és kontraindikációit az 1. táblázat mutatja [4-8].

\section{A csípőarthroscopia szövődményei}

A mütét általános szövődménye lehet a gyulladás, sebgyógyulási zavarok, haematoma kialakulása. Az irodalomban leírásra került a hasüregbe történő folyadékbe-
1. táblázat |A csípőarthroscopia indikációi és kontraindikációi [4-8]

\begin{tabular}{ll}
\hline Indikáció & Kontraindikáció \\
\hline Csípőuitközési szindróma & Abszolút \\
Osteochondralis laesio & Előrehaladott arthrosis \\
Labrumszakadás & Súlyos fokú Legg-Calvé- \\
& Perthes-kór és epiphyseolysis \\
Synovialis chondromatosis & Csípő́izületi ankylosis [7] \\
Ízületi szabad test & Csípőficam \\
Szeptikus arthritis [4] & Súlyos acetabulumretro- \\
& versio \\
\hline A synovialis hártya megbetegedései & Relatív \\
Adhaesiv capsulitis & Középsúlyos arthrosis \\
Instabilitás & Dysplasia \\
TEP-mútét utáni débridement, & Idegi sérülés \\
kontraktúraoldás, ínhosszabbítás [5, 6] & \\
Bursitis trochanterica & Coxa saltans interna súlyos \\
femurnyak-anteversióval & társulva \\
Piriformis szindróma & Obesitas [8] \\
& Súlyos ízületi deformitás
\end{tabular}

Ischiofemoralis és spina iliaca anterior inferior ütközési szindróma

TEP $=$ teljes endoprotézis

áramlás is [9], megfelelő folyadékáramlás-menedzseléssel azonban ez a kockázat csökkenthető. Az extenzió alkalmazása okozhatja a nervus (n.) ischiadicus, a n. cutaneus femoris lateralis, a n. femoralis és a n. pudendus neurapraxiáját [10]. Scrotumnecrosis, heterotrop ossificatio [11], iliopsoastendinitis [12] és arthroscopos eszköz törése is fellelhető a szövődmények leírása között. A csípőarthroscopiával közvetlenül összefüggésben nem került leírásra mélyvénás trombózis és pulmonalis embolia, de mint ismeretes, az alsó végtagokon végzett mütétek esetén ezek kockázata nem hagyható figyelmen kívül, ezért megfelelő LMWH (low-molecular-weight heparin)-prevenció szükséges [13].

$\mathrm{Az}$ anterolateralis portál bevezetése során a következő, irodalomban is fellelhető szövődményekkel lehet számolni: a n. gluteus superior sérülése, labrumsérülés. $\mathrm{Az}$ anterior portál kialakítása során sérülhet a $\mathrm{n}$. femoralis, n. cutaneus femoris lateralis, az arteria (a.) circumflexa femoris lateralis. A mid-anterior portál használata során a fentiek sérülésének kockázata kisebb [14]. A posterolateralis portál esetén a $\mathrm{n}$. ischiadicus, valamint az a. circumflexa femoris medialis sérülése [15] alakulhat ki, melyeket megfelelő mütéti technikával csökkenthetünk. Iatrogén porckárosodás minden portál esetén kialakulhat. A medialis, de fóként a lateralis synovialis redő károsításával sérülhet az a. circumflexa femoris medialis és lateralis, aminek következtében avascularis necrosis alakulhat ki. Sampson [16] femurnyaktörésről is beszámolt, amelyet a kiterjedtebb csontreszekció, valamint a korai teljes terhelés következményeként írt le. 


\section{Módszer}

A betegkiválasztásnál a fizikális vizsgálat során kiváltható flexiós, addukciós és berotációs mozgás közben az inguinalis hajlatban fellépó és fokozódó fájdalom mellett, $\mathrm{AP}$ medence- és Lauenstein-felvételeken talált radiológiai eltérések alapján indikáltuk a mútétet. A diagnózis a csípőütközési szindróma volt. Tannast és mtsai véleménye szerint hagyományos röntgenfelvételekkel könnyú és elégséges diagnosztizálni a csípőütközési szindrómát [17.] Természetesen az MR-vizsgálat a labrumsérülések diagnosztizálásában, valamint a CT-vizsgálat az acetabulumretroversio megítélése esetén [18] részletesebb képet ad, de a jelen kiválasztási kritériumok között nem ezeket határoztuk meg elsődleges vizsgálóeljárásnak, hanem a Tannast és mtsai által leírt ajánlást.

Fektetés: A mütéteket hanyatt fekvésben, extenziós asztalon végeztük, a végtagok közé helyezett, széles gátvédelmet alkalmazva [19]. Osztályunkon a hanyatt fektetésben végzett technikát honosítottuk meg (1. ábra).

A lágyrész-extenzió húzási erejét a beteg paramétereihez próbáltuk igazítani [20]; az extenziós húzás miatt betegeinknél szövődményt nem észleltünk. Az operálni kívánt végtagot nyújtott helyzetben tartva, 10-15 fokos berotációban és flexióban, az ellenoldali végtagot abdukált helyzetbe, semleges rotációba és semleges flexióba
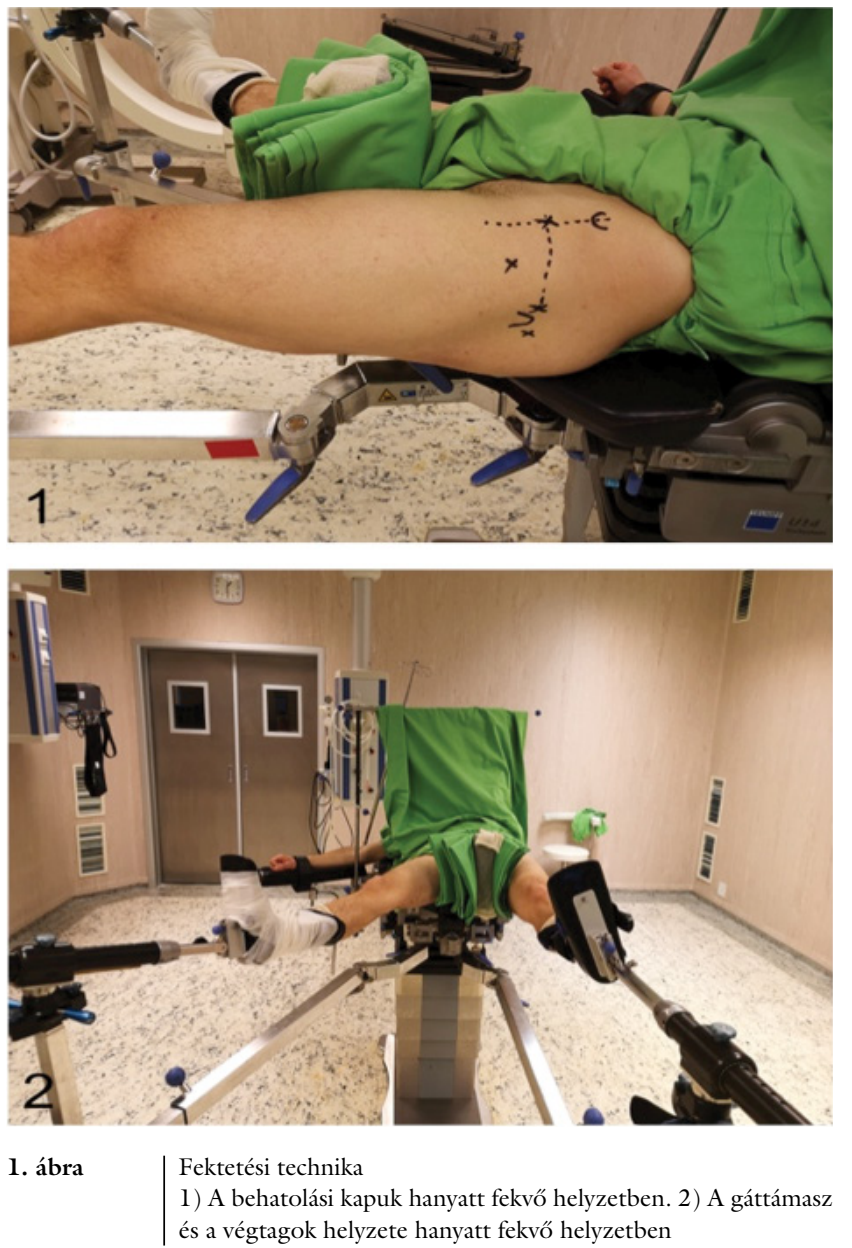

pozicionálva történik a beteg izolációja. Minden esetben képerősítő használatával győződtünk meg a kívánt helyzetről és az extenzió mértékéról. Az extenzió-célérték 10-12 mm, melyet folyamatosan, röntgen-képerősítő használatával ellenőrzünk [21]. Az ideális húzási idő kevesebb, mint 2 óra, ezt a mütét során számon tartottuk, és időkorlátot alkalmaztunk, melyet egy esetben sem léptünk túl. A tervezett mútétet minden esetben befejeztük ezen időkorláton belül.

Metódus: Minden mútét esetén három standard portált használtunk. Az irodalomban több mint 18 portál került leírásra, ezek nagy része azonban csak kiegészítésképpen használatos. A standard portálok meghatározásakor a nagytompor (NT), valamint a spina iliaca anterior superior (SIAS) identifikálása elsődleges. A NT és a SIAS jól tapintható, biztos markerpont minden alkatú beteg esetén. A három standard portál, amelyet használtunk, az anterolateralis portál (ALP), a posterolateralis portál (PLP) és az anterior portál (AP). Az ALP helyzete a NTtól $1 \mathrm{~cm}$-re proximalis és $1 \mathrm{~cm}$-re anterior helyzetben, a PLP helyzete a NT-tól $1 \mathrm{~cm}$-re proximalis és $1 \mathrm{~cm}$-re posterior irányban, az AP helyzete pedig a SIAS és a patella középpontját összekötő egyenesnek, valamint az ALP-ból kiinduló egyenesnek a derékszögben lévő metszéspontjánál található. A mid-anterior portál (MAP) helye distalisan egy képzeletbeli, egyenlő szárú három-
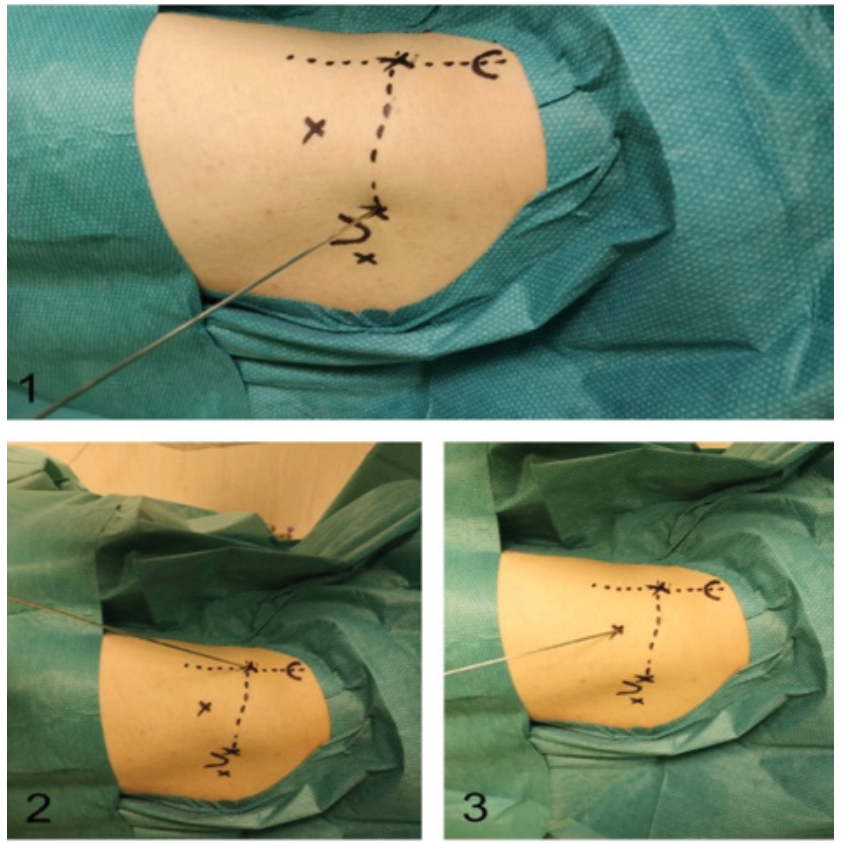

2. ábra

Két fö standard és egy kiegészítő portál helye és a bevezetés irányai

1) Az ALP (anterolateralis portál) helye, a Kirschner-drót a NT tól (nagytompor) $1 \mathrm{~cm}$-re proximalisan és $1 \mathrm{~cm}$-re anterior helyzetben, 20 fokos posterior és 15 fokos cranialis iránnyal. 2) Az AP (anterior portál) helye a SIAS-tól (spina iliaca anterior superior) caudalis irányban húzott és az ALP-tól (anterolateralis portál) erre merőlegesen húzott egyenesek metszéspontjánál, 40 fokos cranialis és 30 fokos medialis irányultsággal. 3 ) A MAP (mid-anterior portál) helye distalisan egy képzeletbeli, egyenlő oldalú háromszög egyik pontjánál képződik 35 fokos cranialis és 25 fokos posterior irányultsággal 
2. táblázat | Standard portálok

\begin{tabular}{lll}
\hline Portál & $\begin{array}{l}\text { A behelyezési szög centrális } \\
\text { kompartment esetén }\end{array}$ & $\begin{array}{l}\text { A behelyezési szög perifériás } \\
\text { kompartment esetén }\end{array}$ \\
\hline AL & $\begin{array}{l}15 \text { fokos cranialis, } 15 \text { fokos } \\
\text { posterior irányban }\end{array}$ & $\begin{array}{l}15 \text { fokos cranialis, } 5 \text { fokos } \\
\text { anterior irányban }\end{array}$ \\
PL & $\begin{array}{l}5 \text { fokos cranialis, } 5 \text { fokos } \\
\text { anterior irányban }\end{array}$ & $\begin{array}{l}25 \text { fokos caudalis, } 15 \text { fokos } \\
\text { anterior irányban }\end{array}$ \\
A & $\begin{array}{l}35 \text { fokos cranialis, } 35 \text { fokos } \\
\text { posterior irányban }\end{array}$ & \\
\hline
\end{tabular}

$\mathrm{A}=$ anterior $; \mathrm{AL}=$ anterolateralis $; \mathrm{PL}=$ posterolateralis

szög egyik pontjánál képződik 35 fokos cranialis és 25 fokos posterior irányultsággal. Az egyenlő szárú háromszög másik két pontja az ALP és az AP [22] (2. ábra).

A SIAS és a patella középpontját összekötő egyenes egyben a határa is annak a biztonságos zónának, amelytől medialis irányban nem ajánlatos eltérni a régióban elhelyezkedő arteria, nervus és vena femoralis sérülésveszélye miatt. Ezen három portál elegendő a centrális kompartment vizualizációjához. A standard portálok bevezetésének irányai az 2. táblázatban láthatók.

Centrális kompartment: Minden esetben a centrális kompartmentet tekintettük át először. Képerősítő alatt Kirschner-drótot vezettünk be az ízületbe megközelítőleg 20 fokos posterior és 15 fokos cranialis irányultsággal az AL portálnak megfelelően. A Kirschner-drót hozzávetőleg 2/3:1/3 arányban került bevezetésre a femurfejhez orientálva. Ezt követően Kirschner-drót által vezetve a trokár behelyezése történt, majd 30 fokos kamerával tekintettük át a csípőízületet. A centrális kompartmentben vizualizáltuk az ízületi tokot, a femurfejet, az acetabulumot, a ligamentum capitis femorist, a pulvinart, a labrumot. Az anterior portál behelyezése típusos helyen történt, a trokárt 40 fokos cranialis és 30 fokos medialis irányultsággal vezetve [23]. Ennek behelyezése után elektrokauterrel, valamint porcborotvával (shaver) és polírozóval (bur) végeztük el a tervezett beavatkozásokat, ami jellemzően chondrectomiát, partialis synovectomiát, débridementet, részleges labrumdébridementet [24], acetabulumperem-plasztikát jelentett (3. és 4. ábra).
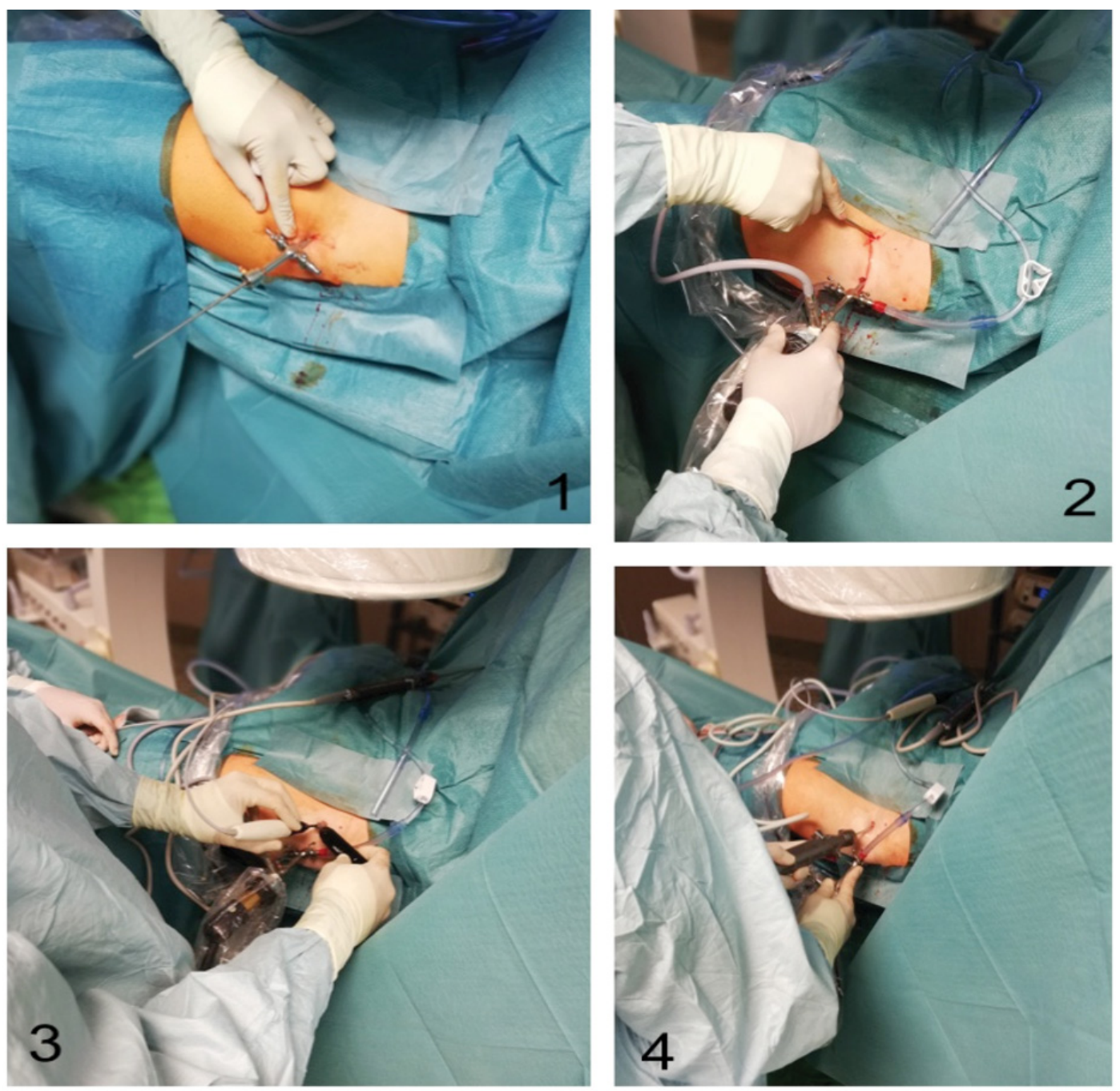

3. ábra

Intraoperatív munka

1) Az anterolateralis portálon keresztül a trokár behelyezése. 2) Az anterior portál megnyitása intraarticularis kontroll mellett.

3) Elektrokauter használata. 4) 'Shaver' használata 

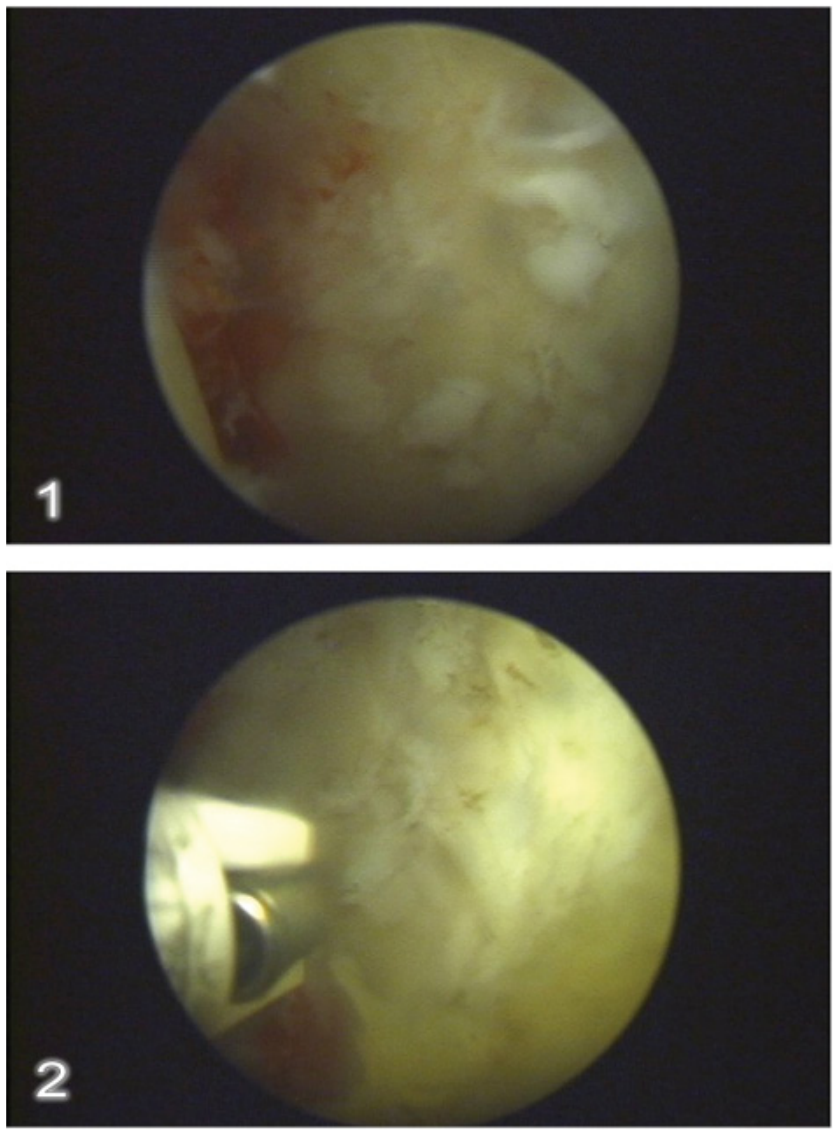

4. ábra $\quad$ Intraarticularis débridement

1) Az acetabulum porcán látható chondropathia. 2) Chondrec tomia elektrokauterrel

Perifériás kompartment: Az extenziót megszüntetve, illetve a térdet 40-45 fokos flexióba hozva, a standard portálokon, valamint a MAP-on keresztül hatoltunk az ízületi tokon keresztül a femurnyakra. Itt vizualizáltuk a medialis és lateralis synovialis redőt, a labrumot, a csontporc határt, a zona orbicularist és a nyakon lévő 'cam' (bütyköstengely) típusú deformitást, amennyiben jelen volt. A medialis synovialis redő 6 óránál, a lateralis redő pedig 12 óránál található, és a benne elhelyezkedő érképletek miatt a megőrzésükre nagy figyelmet kell fordítani [25]. A peritrochantericus kompartentet nem vizualizáltuk. A csípőízületi arthroscopiát követően az ízületi tokot nem zártuk varrattal. Lin és mtsai vizsgálata szerint a tok zárásának nincsenek egyértelműen pozitív előnyei, ezért rutinszerúen nem javasolták zárni az ízületi tokot [26].

\section{Posztoperatív rehabilitáció}

Az osztályunkon alkalmazott rehabilitációs protokoll megegyezik a nemzetközi standard ajánlásokkal. 'Cam' deformitás ellátása esetén 10-14 napos részleges terhelést engedélyeztünk [23] betegeinknek, majd fokozatos ROM- (range of motion) növelés és izomerôsítés következett. A teljes terhelés ezt követően 2 hét alatt elérhe- tővé vált. A csípőarthroscopia utáni rehabilitációs protokoll természetesen nagyban függ a talált egyéb eltérésektől, azok ellátásától. Ezekre vonatkozóan számos cikk közölt adatokat. Egy összefüggő tanulmány szerint a rehabilitációs protokollt személyre szabottan kell kialakítani [27]. Az általunk talált arthroscopos lelet során döntöttünk mi is a rehabilitáció üteméről. A femurnyakon lévő nagyobb 'cam' deformitás eltávolítása például jellemzően eltolta a rehabilitáció idejét a femurnyaktörés elkerülése érdekében, a mélyen reszekált 'cam' deformitás ugyanis 10-30\%-ban növeli a combnyaktörés kockázatát [28]. Amennyiben a reszekció mértékét úgy ítéltük meg, hogy nem növeli ezt a kockázatot, illetve minden egyéb esetben is - amikor például a labrum débridementje mellett döntöttünk - tartottuk magunkat a 2 hetes teljes terhelés eléréséhez.

\section{Betegkiválasztás és statisztika}

2017. 01. 01. és 2019. 04. 15. között 29 mútétet végeztünk. Az elvégzett mütéteket retrospektív vizsgálat keretében vizsgáltuk. Kizárási kritériumot nem határoztunk meg, az összes elvégzett mütét szerepel a kimutatásban. A pre- és posztoperatív állapot megítélésére a preoperatív, valamint a mütét utáni 1 . hónapban végzett posztoperatív módosított Harris-csípőpontértéket (Harris hip score - mHHS) alkalmaztuk [29]. Statisztikailag F-, valamint egy- és kétoldalú t-próbákat végeztünk. A Student-féle t-próba alapján, $\mathrm{p}=0,05$ szignifikanciaszint mellett vizsgáltuk a két csoport közti eltéréseket. Az első csoportba a preoperatív mHHS alapján, a második csoportba a posztoperatív mHHS alapján soroltuk be a betegeket. Szignifikáns különbségról $\mathrm{p}=0,05$ érték alatt beszélhetünk. Egyoldalú próba esetén feltételeztük, hogy csak egyirányú változás állhat be („javulás”); kétoldalú próba esetén feltételeztük, hogy akár mindkét irányú változás („javulás” vagy „romlás”) létrejöhet a két csoport között. Mindkét próbát elvégeztük, ez azonban nem befolyásolta a statisztikai kimenetelt. Microsoft Excel (Microsoft Corporation, Redmond, WA, Amerikai Egyesült Államok [USA]) és Systat SigmaPlot (Systat Software Inc., San Jose, CA, USA) szoftvereket használtunk azonos eredményekkel.

\section{Eredmények}

Osztályunkon 2017. 01. 01. és 2019. 04. 15. között 29, hanyatt fekvésben történt csípőarthroscopiát végeztünk, 30 fokos optikával, jellemzően anterolateralis, posterolateralis és anterior behatolási kapukból. Az indikáció jellemzően a csípőütközési (hip impingement) szindróma volt. Izolált 'cam' deformitást 3 (10,34\%), izolált 'pincer' (csipesz) típusú deformitást $9(31,05 \%)$, kevert deformitást $13(44,82 \%)$ esetben találtunk. Az általunk végzett mütétek során 4 esetben (13,79\%) kiegészítő miniarthrotomia vált szükségessé. A 29 betegből 13 férfi $(44,82 \%)$ és 16 nő $(55,18 \%)$ volt. Jobb oldali csípő 15 
$(51,72 \%)$, bal oldali $14(48,28 \%)$ esetben került operációra. Az átlagéletkor 44,1 (22-60) év volt. A preoperatív átlagos alfa szög férfi beteg esetén 97, nőbeteg esetén 89 foknak mérődött. Az átlagos mütéti idő 47 perc, az átlagos ápolási napok száma 5,8 nap volt. Mútéteink során major szövődményt nem tapasztaltunk. 5 (17,24\%) esetben a panaszok a mütét után sem csökkentek. Iatrogén chondralis károsodás 2 esetben $(6,89 \%)$ alakult ki. 24 esetben $(82,76 \%)$ a betegek a panaszaik csökkenéséról számoltak be a kontrollok során. Véleményünk szerint a panaszok mütét utáni stagnálásának oka legfőképpen a nem megfelelő preoperatív indikáció megválasztása lehetett.

Statisztikai eredmények: F-próba: 0,101, ennek alapján $\mathrm{p}=0,05$ szignifikanciaszint mellett a két csoport homoszkedasztikus. A Student-féle t-próbák eredményei: $\mathrm{T}$ ( 1 oldalú próba): $1,16 \times 10^{-7}$ és T $(2$ oldalú próba): $2,33 \times 10^{-7}$. Ezen értékek alapján eredményeink szignifikánsnak tekinthetők. Az átlagos preoperatív mHHS 73,06 pont $(60,5-82,5)$, az átlagos posztoperatív $\mathrm{mHHS}$ pedig $87,27(66-100,1)$ volt.

\section{Megbeszélés}

Véleményünk szerint a csípőarthroscopia megfelelő alternatíva a csípő operatív tevékenységei között, ám tapasztalataink is alátámasztják a szakirodalom általános véleményét, miszerint a műtét elsajátítása hosszú 'learning curve'-t igényel; ezért - tapasztalataink szerint - feltétlenül egy, az arthroscopiában járatos sebész kompetenciájába kell, hogy tartozzon ezen profil felépítése.

Eredményeink korrelálnak a témában közölt nemzetközi eredményekkel. Számos szerző vizsgálta a rövid, közép- és hosszú távú eredményeket a posztoperatív panaszok csökkenését kimutatva, és számolt be kis százalékban előforduló szövődményekről.

Byrd és mtsai írták le elsőként - heterogén populációt vizsgálva - a csípőarthroscopia pozitív eredményeit. 38 mútétet végeztek 35 betegen, 2 éves utánkövetést vizsgáltak, és szignifikánsan jó eredményt mutattak ki a beavatkozásnak köszönhetően [30]. O’Leary és mtsai 86 esetben végeztek csípőarthroscopiát, és a mütét utáni eredményeket szignifikánsan jónak írták le [31]. Chen és mtsai kimutatták, hogy részleges labrumdébridement esetén, szűk indikációval kiválasztva a betegeket, szignifikánsan jó eredményeket lehet elérni csípőarthroscopia során [32]. Menge és mtsai 149 csípőarthroscopiát elvégezve és statisztikailag elemezve szintén azt találták, hogy szignifikánsan javultak a posztoperatív eredmények a beteg panaszai tekintetében [33].

A mütéti technika osztályunkon történt kialakításakor a következő irodalmi tényeket vettük alapul:

Az oldalt és hanyatt fekvő helyzetben végzett mütét során jelentős különbség nem került leírásra az irodalomban [34].

A fellelhető adatok szerint az extenzió miatti szövődmények csökkenthetők a Trendelenburg-helyzetben végzett, gáttámasz nélküli extenzió alkalmazásával [35], melynek bevezetését a jövőben mi is tervezzük.

A nemzetközi irodalomban fellelhető közlemények szerint a kiegészítő portálok protokollszerú használata nem adja meg azt a többletsegítséget, amelyet érdemes vállalni a rizikófaktorok figyelembevételével [36]. Természetesen egyedi esetben van létjogosultsága a leírt segédportálok használatának is. Az irodalomban találtunk közleményt az ún. 'single-portal' (egy portálon keresztüli) technikáról is, ennek indikációja azonban szúkebb, valamint pontosabb preoperatív diagnosztikát is igényel [37].

Vizsgálataink korlátai közé sorolandó a kis esetszám, a rövid utánkövetési idő, a preoperatív vizsgálatok értékelésének megbízhatósága, a betegek megfelelő kiválasztásának képessége, az arthroscoposan realizált intraarticularis patológia megértése és értelmezése, valamint az arthroscopia elvégzéséhez szükséges készségek és technológia rendelkezésre állása. Ezek a korlátok a gyakorlat megszerzésével, idővel természetesen eltűnhetnek.

Cikkünkben a Magyarországon ritkaságszámba menő csípőarthroscopos eljárást és az ebben szerzett korai tapasztalatunkat osztjuk meg a szakma képviselőivel. Ezen tanulmány későbbi kutatások és utánkövetéses vizsgálatok alapja, ösztönzője lehet. Megfelelő szakmai, személyi és tárgyi feltételek teljesülése esetén a csípőízület arthroscopos ellátása kevesebb szöveti megterhelést okozó, rövidebb rehabilitációt igénylő, kisebb kockázatú mód lehet a csípő egyes kórképeinek kezelésében.

Anyagi támogatás: A szerzők anyagi támogatásban nem részesültek.

Szerzői munkamegosztás: Zs. Zs.: Mütéti technika, kutatómunka, az irodalom áttekintése, a cikk megírása, szerkesztése, a fényképek készítése és szerkesztése, a táblázatok elkészítése. G. A.: Statisztikai elemzés. P. M.: A műtéti technika és a szakirodalom áttekintése. A cikk végleges változatát mindhárom szerző elolvasta és jóváhagyta.

Érdekeltségek: A szerzőknek nincsenek érdekeltségeik.

\section{Irodalom}

[1] Kautzner J, Zeman P, Stančák A, et al. Hip arthroscopy learning curve: a prospective single-surgeon study. Int Orthop. 2018; 42: 777-782.

[2] Schüttler KF, Schramm R, El-Zayat BF, et al. The effect of surgeon's learning curve: complications and outcome after hip arthroscopy. Arch Orthop Trauma Surg. 2018; 138: 1415-1421.

[3] Burman MS. Arthroscopy or direct visualization of joints: an experimental cadaveric study. Am J Bone Joint Surg. 1931; 13: 669-695

[4] El-Sayed AM. Treatment of early septic arthritis of the hip in children: comparison of results of open arthrotomy versus arthroscopic drainage. J Child Orthop. 2008; 2: 229-237. 
[5] Lachiewicz PF, Kauk JR. Anterior iliopsoas impingement and tendinitis after total hip arthroplasty. J Am Acad Orthop Surg. 2009; 17: 337-344.

[6] Van Riet A, De Schepper J, Delport HP. Arthroscopic psoas release for iliopsoas impingement after total hip replacement. Acta Orthop Belg. 2011; 77: 41-46.

[7] Byrd JW. Hip arthroscopy. J Am Acad Orthop Surg. 2006; 14: 433-444.

[8] Ross JR, Larson CM, Bedi A. Indications for hip arthroscopy. Sports Health 2017; 9: 402-413.

[9] Byrd JW, Chern KY. Traction versus distension for distraction of the joint during hip arthroscopy. Arthroscopy 1997; 13: 346349.

[10] Sampson TG. Complications of hip arthroscopy. Tech Orthop. 2005; 20: 63-66.

[11] Gao GY, Zhang X, Dai LH, et al. Heterotopic ossification after arthroscopy for hip impingement syndrome. Chin Med J. 2019; 137: 827-833.

[12] Adib F, Johnson AJ, Hennrikus WL, et al. Iliopsoas tendonitis after hip arthroscopy: prevalence, risk factors and treatment algorithm. J Hip Preserv Surg. 2018; 5: 362-369.

[13] Bushnell BD, Anz AW, Bert JM. Venous thromboembolism in lower extremity arthroscopy. Arthroscopy 2008; 24: 604-611.

[14] Robertson WJ, Kelly BT. The safe zone for hip arthroscopy: a cadaveric assessment of central, peripheral, and lateral compartment portal placement. Arthroscopy 2008; 24: 1019-1026.

[15] Sussmann PS, Zumstein M, Hahn F, et al. The risk of vascular injury to the femoral head when using the posterolateral arthroscopy portal: cadaveric investigation. Arthroscopy 2007; 23: $1112-1115$

[16] Sampson TG. Arthroscopic treatment of femoroacetabular impingement. Tech Orthop. 2005; 20: 56-62.

[17] Tannast M, Siebenrock KA, Anderson SE. Femoroacetabular impingement: radiographic diagnosis - what the radiologist should know. Am J Roentgenol. 2007; 188: 1540-1552.

[18] Perreira AC, Hunter JC, Laird T, et al. Multilevel measurement of acetabular version using 3-D CT-generated models: implications for hip preservation surgery. Clin Orthop Relat Res. 2011; 469: 552-561.

[19] Nasser R, Domb B. Hip arthroscopy for femoroacetabular impingement. Effort Open Rev. 2018; 3: 121-129.

[20] Ellenrieder M, Tischer T, Bader R, et al. Patient-specific factors influencing the traction forces in hip arthroscopy. Arch Orthop Trauma Surg. 2017; 137: 81-87.

[21] Sonnenfeld JJ, Trofa DP, Mehta MP, et al. Hip arthroscopy for femoroacetabular impingement. JBJS Essent Surg Tech. 2018; 8: e23.

[22] Aprato A, Giachino M, Masse A. Arthroscopic approach and anatomy of the hip. Muscles Ligaments Tendons J. 2016; 6: 309-316.
[23] Byrd JW, Bedi A, Stubbs AJ, et al. (eds.) The Hip: AANA Advanced Arthroscopic Surgical Techniques. SLACK Incorporated, Thorofare, NJ, 2016.

[24] Su T, Chen GX, Yang L. Diagnosis and treatment of labral tear. Chinese Med J. 2019; 132: 211-219.

[25] McCormick F, Kleweno CP, Kim YJ, et al. Vascular safe zones in hip arthroscopy. Am J Sports Med. 2011; 39(Suppl): 64S-67S.

[26] Lin Y, Li T, Deng X, et al. Repaired or unrepaired capsulotomy after hip arthroscopy: a systematic review and meta-analysis of comparative studies. Hip Int. 2019 Sep 30. doi: 10.1177/ 1120700019880818. [Epub ahead of print]

[27] Grzybowski JS, Malloy P, Stegemann C, et al. Rehabilitation following hip arthroscopy - a systematic review. Front Surg. 2015; 2: 21 .

[28] Horner NS, Vikas K, MacDonald AE, et al. Femoral neck fractures as a complication of hip arthroscopy: a systematic review. J Hip Preserv Surg. 2017; 4: 9-17.

[29] Byrd JW, Jones KS. Hip arthroscopy in the presence of dysplasia. Arthroscopy 2003; 19: 1055-1060.

[30] Byrd J, Jones KS. Prospective analysis of hip arthroscopy with 2-year follow-up. Arthroscopy 2000; 16: 578-587.

[31] O'Leary JA, Berend K, Vail TP. The relationship between diagnosis and outcome in arthroscopy of the hip. Arthroscopy 2001; 17: 181-188.

[32] Chen AW, Yuen LC, Ortiz-Declet V, et al. Selective debridement with labral preservation using narrow indications in the hip: minimum 5-year outcomes with a matched-pair labral repair control group. Am J Sports Med. 2018; 46: 297-304.

[33] Menge TJ, Briggs KK, Dornan GJ, et al. Survivorship and outcomes 10 years following hip arthroscopy for femoroacetabular impingement: labral debridement compared with labral repair. J Bone Joint Surg Am. 2017; 99: 997-1004.

[34] de Sa D, Stephens K, Parmar D, et al. A comparison of supine and lateral decubitus positions for hip arthroscopy: a systematic review of outcomes and complications. Arthroscopy 2016; 32: 716-725.e8.

[35] Mei-Dan O, Kraeutler MJ, Garabekyan T, et al. Hip distraction without a perineal post: a prospective study of 1000 hip arthroscopy cases. Am J Aports Med. 2018; 46: 632-641.

[36] Thorey F, Ezechieli M, Ettinger M, et al. Access to the hip joint from standard arthroscopic portals: a cadaver study. Arthroscopy 2013; 29: 1297-1307.

[37] Mannava S, Howse EA, Kelsey TJ, et al. Single-portal arthroscopy of the central compartment of the hip. Arthrose Tech. 2015; 4: e273-e277.

(Zsákai Zsolt dr., Miskolc, Pf. 680, 3548 e-mail: zsakaizsolt@zsakaizsolt.com)

A cikk a Creative Commons Attribution 4.0 International License (https://creativecommons.org/licenses/by/4.0/) feltételei szerint publikált Open Access közlemény, melynek szellemében a cikk bármilyen médiumban szabadon felhasználható, megosztható és újraközölhető, feltéve, hogy az eredeti szerző és a közlés helye, illetve a CC License linkje és az esetlegesen végrehajtott módosítások feltüntetésre kerülnek. (SID_1) 